\title{
Brazilian Journal of Mother and Child Health - young but already with a history
}

History is fact but not the years. History is established, definitely, by its meaning. The presence of the facts that reveal the substance of the world and therefore its understanding allows us to glimpse into the future! We appreciate this possibility, vision or ideal because we can search for the meaning, by making mistakes or correcting them, however, the conjecture that we could do to follow ahead envisioning the possibilities that have not reached us yet. Therefore we can say: hope is not the last to die. An idea that goes hand in hand, changes, but never dies!

Thus, this happens to an analysis, even if it is superficial, the history of many scientific journals allows us to witness the evidence of what we are saying. Journals throughout its history have promoted changes, specifying in a better way; widening or reducing the scope, the depth of addressing the articles, the level of demands required for publication, the priority of its themes or its periodicity, ended by achieving a level of excellence. And, for this reason, many Journals have a beautiful historical experience in publishing fundamentally important and even revolutionary articles. Some are recognized in the fields of scientific community, general science, and even, particularly, philosophy of science, are notable publications that have changed the course of human knowledge. We cannot at all ignore any of this, for example, its own creation and an editorial opportunity in the first scientific journal, the Transactions of Philosophycal Society in England in the 17th century generating a culture to publish scientific articles which continues to increase until nowadays 1 ; many journals have created or maintain its prestige by publishing seminal articles.

As a close example in our time, it is important to mention about Einstein's published articles in 1905 in Annalen der Physic; or Watson and Crick's publication of an article on the discovery of the DNA structure in 1953 in Nature Journal, or our publication on the Memórias do Instituto Oswaldo Cruz, (Memories of Oswaldo Cruz Institute) which enabled the exhibition of Brazilian researches in the field of parasitology, so important for a better understanding of the so-called tropical diseases.

Fortunately this experience extends to other less known and still young journals. In Brazil, the existence of a journal such as The Journal of Venomous Animals and Toxins including Tropical Diseases is the only journal whose scope is precisely on research exposure related to fauna of venomous species, also important on the studies of those diseases. However, it would be so disappointing if Brazil did not publish a journal like this. In another remarkable field is the existence of the Brazilian journals such as Cadernos de Saúde Pública and Revista de Saúde Pública (Public Health Journal) whose scopes deal with the most fundamental health issues in our country and in developing countries, which brings the most significant facts from the point of view of human development. It is unnecessary to comment on the importance to publish in these journals, the most relevant articles. These deserve to be read not only in Brazil, but elsewhere.

A journal as the Brazilian Journal of Mother and Child Health (Revista Brasileira de Saúde Materno Infantil -RBSMI), a publication less than 20 years of existence might have something to say as well. Thus, we would like to emphasize with much conviction that our journal is inserted in a context of facts and progress which has already offered its pages to announce important scientific publications of materials and fundamental findings which deserve to be reread. For example, Prof. Philip Musgrove's article in 2001, in the beginning of our journal, entitled "What is the minimum a doctor should know about health economics?", 2 whose republication for its relevance was performed by the author, under the license and authorization of our Journal in the book Health Economics in Development edited by the World Bank ${ }^{3}$; as well as other important articles such as "What not to do in medical statistics" 4 by Neal Alexander or "Exfoliated epithelial cells: potentials to explore gastrointestinal maturation of preterm infants" 5 by B. Kaeffer. As a world reference of the RBSMI we cannot 
forget to mention our presence among hundreds of international journals in the editorial forum "Global Theme Issue or Poverty and Human Development"sponsored by Fogarty International Center and the National Library of Medicine in 2007 including publications of five articles V.7 (4): 457-93 (2007).

It is important to note that the journal remains attentive on scientific issues, not only in clinical area but especially in community health, the essence of its scope. For this reason the journal was present at a moment of the worst health problems in the publication of a special edition V.16 (3) 2016, providing the most current research investigation and health care - at the Instituto de Medicina Integral Prof. Fernando Figueira (IMIP), a sponsor of the Journal - on arboviruses, especially addressing the issue on microcephaly associated to Zika in children who were treated and studied during this epidemic moment which was identified at IMIP, at the beginning of the epidemic in 2015.

These are some reasons why we have mentioned at the beginning that history is fact but not the years. Our Journal has a few years of existence, we are young, but we have facts. This is the mark of our history.

\section{References}

1. Mabe M. The growth and number of journals. Serials. 2003; 16 (2): 191-7.

2. Musgrove P. What is the minimum a doctor should know about health economics? Rev Bras Saúde Matern Infant. 2001; 1 (2): 103-9.

3. Musgrove P. What is the minimum a doctor should know about health economics? In: Health Economics in Development. Washington, DC: The World Bank; 2004. p. 23-33.

4. Alexander N. What not to do in medical statistics. Rev Bras Saúde Matern Infant. 2007; 7 (3): 327-38.

5. Kaeffer B. Exfoliated epithelial cells: potentials to explore gastrointestinal maturation of preterm infants. Rev Bras Saúde Matern Infant. 2010; 10 (1): 13-24.

José Eulálio Cabral Filho 1

${ }^{1}$ Executive Editor of the Braziilan Journal of Mother and Child Health . Recife, PE, Brazil. 